\title{
DOI 10.15407/mics2020.10.041
}

\section{УДК 94(477.83)}

\section{Орися Віра,}

магістерка історії, аспірантка кафедри класичних,

візантійських і середньовічних студій Украӥнського католииького університету vira@ucu.edu.ua

\section{https://orcid.org/0000-0003-0750-2954}

\section{ГЕНЕЗА ТА ФУНКЦІОНУВАННЯ НАЗВ ВУЛИЦЬ У СЕРЕДНЬОВІЧНОМУ ЛЬВОВІ}

Згідно з «просторовим поворотом», простір у містах потрібно розглядати не лише в контексті сочіальних проиесів, але також як продукт людської діяльності та уяви. Назви вулииь є невід'ємною частиною уявлення людей про простір в місті. У середньовічні та ранньомодерні часи назви нерозривно пов'язувались із об'єктами, ремісниками чи громадами, шо проживали на території. Тож $і$ досліджувати назви варто в їх хронологічному розвитку та в поєднанні з простором. Найчастіше назви львівських вулиць згадуються в довідниках з перейменування та вивчалися, переважно, на краєзнавчому рівні. Це означає, щзо назви вулиць у Львові іноді ставали предметом домислів та обростали багатовіковими міфами. Це дослідження спрямоване на з'ясування процесів перейменування, вивчення генезису таких назв та відображення їх на карті за допомогою геоінформачійної системи. Це пояснить і дасть нам краме розуміння їх формування.

Як перший крок у иуьому дослідженні було створено базу даних назв вулиць Львова у 1382-1768 роках. Податкові записи були первинним джерелом, а книги міськоӥ ради -допоміжним. У иій базі даних кожна назва вулиці мас унікальний ідентифікатор. Потім було створено геоінформаційну систему (додаток QGIS 2.18). Вона має три шари: перший містить карту Львова Фрідріха фон Міга (ХVIII століття), другий - сучасну, а третій - об'єкти (вуличі), до яких приєднані імена з бази даних. Завдяки ідентифікатору програма вибирає лише потрібну назву вулииі та хронологічно відображає ї̈ розвиток. Це дає змогу проаналізувати зміни назв вулиць, їх приблизне розташування та зрозуміти витоки деяких міфів щуодо назв вулиць Львова. Наприклад,

(C) Вiра Орися, 2020 
${ }^{1} 1382$ р. - це рік перших зафіксованих назв зі збережених міських книг. 1527 р. - умовна дата «кінця» середньовіччя у Львові, адже цього року відбулась значна пожежа в середмісті, після якої, за хроніками, звели кам'яне місто.

${ }^{2}$ Мельник, Б. (2001). Довідник перейменувань вулиць і площ Львова. ХІІІ-ХХ століття. Львів: Світ.

3 Зокрема датування перших згадок вулиць, а подекуди і їх розташування.

Наприклад, згідно з довідником, перша згадка про вулицю Пальчиковську - 1542 р., хоча запис у міській книзі 1507-1530 pp. фіксує platea palczykowska y 1517 p. Або ж вулиця Шпитальна за довідником, вперше з'являється 1501 р., однак у лавчиній книзі 1441-1448 рр. першу згадку про der gassen kegen den spital (вулиця біля шпиталю) датовано 1442 p. А вже як platea hospitalis (вулиця Шпитальна) - 1461 р.

${ }^{4}$ Крип’якевич, I. (1965). Топоніміка старого Львова. Науково-інформаційний бюлетень архівного управління УРСР, 5 (67), 85-87.

${ }^{5}$ Крип'якевич, I. (1991). Історичні проходи по Львові. Львів: Каменяр.

${ }^{6}$ Долинська, М. (1996). Ретроспективна метода дослідження забудови середмістя Львова. В Урбаністично-архітектурні проблеми міст Галичини. Львів, 56-62; Ії̈ ж. (1999). Українські квартали в часі австрійського періоду Львова. Книга міст Галичини. Міждисциплінарні дослідження у містознавстві. Вісник Державного університету «Львівська політехніка», 379, 199204; Ї̈ ж. (2001). «Вступ до соціотопографіії», як узагальнений метод історико-архівних попередніх досліджень в реставрації архітектурних

об’єктів. Вісник Національного університету «Львівська політехніка». Архітектура, 429, $166-173$.

7 Долинська, М. (2006). Історична топографія Львова XIV-XIX cm. Львів: Видавництво Національного університету «Львівська політехніка». аналізуючи формування назви вулиці «Sutorum / Szewska» (вуличя Шевська), з’ясовано, щуо будівля та розташування єзуїтської ичеркви вплинули на сприйняття навколишнього простору, тому назва вулиці стала подвійною: «Єзуїтська або Вулиия Шевська». Другий приклад показує, щчо назва вулииі «Зарванська / Сербанська» походить від старопольського слова, щуо означає «галасливий ринок», а не від сербів, які осіли в місті набагато пізніше, ніж виникла назва вулииі.

Ключові слова: Львів, назви вулиць, геоінформаційні технології, вулиця Зарванська, вулиия Шевська.

$\mathrm{H}$

азивництво формувалось разом із містом. Поставали будинки та квартали, зводилися мури та освоювалися передмістя. Із часом простір отримував назву. Генезу і формування урбанонімів варто досліджувати нероздільно від самого міського простору та в історичному контексті.

Основний акцент цього дослідження назв вулиць Львова зроблено на середньовічному періоді магдебурзького міста (1382-1527 рр. ${ }^{1}$ ) з необхідними екскурсами у ранньомодерний час (XVIXVIII ст.), які підкреслюють тривалість формування назв у часі.

Історією львівських вулиць (та історією їхніх назв) займався лише Борис Мельник². Під його авторством було видано довідник перейменування вулиць і площ Львова (XIII-XX ст.). Там подано назви вулиць різних періодів в алфавітному порядку, перші (зафіксовані автором) письмові згадки та їхні сучасні відповідники. Звісно, такі обширні хронологічні рамки не дали автору змоги дослідити все ретельно, особливо це стосується назв середньовіччя та ранньомодерності ${ }^{3}$. Значний внесок у вивчення етимології львівських міських назв зробив історик Іван Крип'якевич. У його розвідці ${ }^{4}$ назви вулиць поділено на декілька груп за ознаками (їх розташування щодо географічних об'єктів, національна і професійна належність); перелічено також назви вулиць на передмістях, які утворювалися від прізвищ власників і від сакральних споруд. Також у своїй відомій праці ${ }^{5}$ він торкається питань розташування вулиць та походження деяких назв. Найбільше до питань львівського називництва зверталась професорка Мар'яна Долинська. В дослідженнях ${ }^{6}$ вона використовувала годоніміку як складову соціотопографічного методу для ретроспективної локалізації нерухомості в містах. Її праці присвячені теоретичним проблемам соціотопографії та безпосередньо історичній топографії Львова ${ }^{7}$. Незважаючи на цінність цих досліджень, у поєднанні з сучасними технологіями можна досягнути кращої візуалізації та чіткішої локалізації певних об’єктів. 


\section{МІсто: ІСТОРІЯ, КУЛЬТУРА, СУСПІЛЬСТВО}

${ }^{8}$ Лam. platea Haliciensis - розташований у середмісті. Від цієї вулиці й одноіменних воріт починалася дорога до міста Галича, колишньої столиці Галицько-Волинського князівства. (Усі назви вулиць в оригінальному написанні (латинські, німецькі та польські) і роки їх існування в примітках подано за базою даних геоінформаційної системи.)

${ }^{9}$ Лam. platea Sokolnicensis - вперше згадано у 1520 р. Вулиця вела в напрямку до села Сокільники, починалась мостом через річку Полтву, який теж мав назву Сокільницький. Приблизно збігається з початком сучасної вулиці М. Коперника.

${ }^{10}$ Лam. mons calecarum aбo platea Caliczagora - 3 1472 р. згадується лише як гора. В 1516 р. вперше вживається з денотатом «вулиця», хоча по-

бутують два варіанти. Аналіз платників податків (із другої половини XVI ст.) з цієї вулиці свідчить, що це були звичайні передміщани, які сплачували шос, відповідно до свого майна і статусу (це спростовує здогад, що в цій місцевості жили найбідніші мешканці міста). Детальніше про статус жебраків див.: Гошко, Т. (2017). Жебраки у руських містах XV - першої половини XVII ст. Україна в Центрально-Східній Свропі, 17, 462-490.

Назва «Каліча гора» найпевніше виникла через те, що там розмішувався шпиталь св. Лазаря, який слугував притулком для жебраків і вбогих. Згодом, за Зиморовичем, у 1618 р. «лазарет перенесли з Калічої гори на Сокільницький гостинець», однак назва за інерцією залишилась. Була відновлена в 1990-х рр., хоч і без урахування ії початкової локації.

${ }^{11}$ Лam. platea Castrensis, plathea ante parvum castrum - вела до Низького замку в середмісті.

12 Лат. platea Ruthenorum - приблизно сучасна вул. Руська.

${ }^{13}$ Лаm. plathea Tartharorum - умовно, сучасна вул. Краківська.

14 Лаm. Platea Pistorum - частина сучасної вул. Театральної.

15 Лаm. Serrifabrorum platea - була на Галицькому передмісті перед Галицькою брамою. Назву згадано у шосових реєстрах $1571-1598 \mathrm{pp}$

16 Лат. Temryczowa platea - вулицю можна приблизно окреслити між парною стороною сучасних вул. Личаківської та вул. М. Лисенка. За чернеткою «Головного інвентаря...», у 1449 р. Миколай Темрич викупив півтора лану в Петра Кушніра (Долинська, М. Історична топографія, 286). Від імені власника лану і пішла назва вулиці - «Темричівська».

${ }^{17}$ Лam. platea Abrkowska - вперше трапляється у 1522 р. Вулиця позначала територію Абрковського лану. Походить від прізвища двох братів Андрія і Миколи Абрків. 31582 р. і надалі назва існує у варіанті «вулиця Габрковська» - Habrkowska platea

${ }^{18}$ Капраль, М. (1997). Власники нерухомости середмістя Львова 30-40-х років XVI століття у світлі шосових реєстрів (соціотопографічний аспект). Записки Наукового товариства імені Шевченка, 233: Прачі Історично-філософської секиї̈, 148. 
${ }^{19}$ Czaja, R., \& Noga, Z. (2015). "Heterogeniczność przestrzeni miejskiej w Królestwie Polskim i Rzeczypospolitej Obojga Narodów w epoce przedprzemysłowej”. Kwartalnik Historii Kultury Materialnej, 63 (2), 183.

${ }^{20}$ Gregory, I. N. A Place in History: A Guide to Using GIS in Historical Research. Retrieved from http:/hds.essex.ac.uk/g2gp/gis/index.asp.

${ }^{21}$ Долинська, М. Історична топографія, 36-86.

${ }^{22}$ Центральний державний історичний архів України, м. Львів (далі - ЦДІАУЛ), (магістрат м. Львова). Ф. 52, оп. 2, спр. 769-813.

${ }^{23}$ Czołowski, A. (Wyd.). (1892). Pomniki dziejowe Lwowa z archiwum miasta (Tom I. Najstaesza księga miejska 1382-1389). Lwow; Czołowski, A. (Wyd.). (1896). Pomniki dziejowe Lwowa z archiwum miasta (Tom II. Księga przychodow i rozchodów miasta 1404-1414). Lwow; Czołowski, A. (Wyd.). (1905). Pomniki dziejowe Lwowa z archiwum miasta (Tom III. Ksiega przychodow i rozchodów miasta 1414-1426). Lwow.

${ }^{24}$ Czołowski, A., \& Jaworski, F. (Wyd.). (1921). Pomniki dziejowe Lwowa z archiwum miasta (Tom IV. Księga ławnicza miejska 1441-1448). Lwow.

${ }^{25}$ ЦДІАУЛ. Ф. 52, оп. 2, спр. 8-10.
У пізньосередньовічний та ранньомодерний час назви виникали завдяки самим міщанам. Вони були реально мотивовані, не закріплені постановами міської влади (наскільки це досліджено станом на сьогодні), тож могли змінюватися. Але змінювались вони впродовж певного часу, переважно через зміни на тлі міста. Саме тому назви потрібно розглядати в «часі їх довгої тривалості». Оскільки міське називництво нероздільно пов’язане 3 простором, неможливо досліджувати їх окремо один від одного, адже «простір міста - це не лише місце, де відбуваються соціальні процеси, а й продукт людської діяльності і уяви» ${ }^{19}$

Поставлені завдання можна реалізувати завдяки розвитку цифрових технологій, зокрема геоінформаційних, які «поєднують у собі системи управління базами даних з інформацією про місце розташування; здатні керувати, обробляти, аналізувати та відображати дані, які просторово прив’язані до поверхні землі» ${ }^{20}$. Одним із інструментів цієї сфери є програма QGIS [2.18].

Спираючись на праці професорки Мар’яни Долинської, яка є авторкою методики ретроспективної локалізації нерухомої власності ${ }^{21}$, розроблено власну методику дослідження назв вулиць, яка передбачає створення геоінформаційної системи з назвами вулиць Львова, що передбачає кілька таких етапів.

Перший етап полягав у збиранні назв вулиць, які були зафіксовані у джерелах. Найкращим джерелом для дослідження назв $є$ податкові (шосові) книги ${ }^{22}$ - це серійні однотипні документи, за даними яких можна простежити динаміку назв (із даних книг узято назви 1535-1768 рр.). Та оскільки такі реєстри вели лише у XVI-XVIII ст., назви вулиць ранішого періоду можна знайти у найдавніших міських книгах - трьох книгах прибутків і видатків (1382-1426 рр.) $)^{23}$ та одній лавничій книзі (1441-1448 pр. $)^{24}$, а також книгах ради (1461-1542 рр. $)^{25}$, в яких містяться витяги з актів купівлі-продажу, запоруки, угоди при розділі майна, тестаменти, карні справи та багато іншого. Таким чином, за зазначеними джерелами, зафіксовано назви 1382-1768 pp.

Другий етап - це впорядкування знайдених назв за хронологією та укладення їх у таблиці.

Третій - переклад назв українською мовою, адже всі знайдені назви були латинською, німецькою та польською мовами.

Четвертий - укладення бази даних для геоінформаційної системи, яка містить такі дані: назву вулиці в оригіналі, ID, день, місяць (якщо відомо) і рік збирання шосового податку або запису судової справи, переклад назви вулиці українською мовою, джерело (фонд, опис, справа, аркуш), мова оригіналу.

Кожній назві вулиці було надано унікальний ідентифікаційний номер. Оскільки всі назви були укладені хронологічно, завдяки ID, програма витягує з бази даних лише потрібну назву.

Для останнього етапу потрібно було вибрати історичну мапу, на якій би зображувались вулиці. Було вибрано одну мапу з корпусу військово-топографічного картографування часів Йосифа II 
${ }^{26}$ Петришин, Г. (2006). «Карта Ф. Фон Міта» (1779-1782 рр.) як джерело до містознавства Галичини. Львів: Видавництво Національного університету «Львівська політехніка», 10.

Рuc. 1. Вигляд третього шару геоінформаційної системи з умовним розташуванням вулиць

${ }^{27}$ Долинська, М. Історична топографія, 183-205. (імператор Священної Римської імперії (1765-1790; до 1780 р. правив разом зі своєю матір'ю Марією-Терезією, від якої успадкував Габсбурзькі володіння), яка відома за іменем керівника проекту - Фрідріха фон Міга (1731-1783), інженера, обер-лейтенанта квартирмейстерства австрійського генерального штабу ${ }^{26}$. Мапа Львова належить до топографічних описів Галичини, які були створені упродовж 1779-1782 рр., незадовго після переходу цієї території під владу Габсбурзької монархії, тож на них детально відображено стан міста до «австрійської перебудови».

Першим шаром геоінформаційної системи буде сучасна карта. Другим - мапа фон Міга. На третьому шарі (рис. 1) є відображені об'єкти-полігони (вулиці).

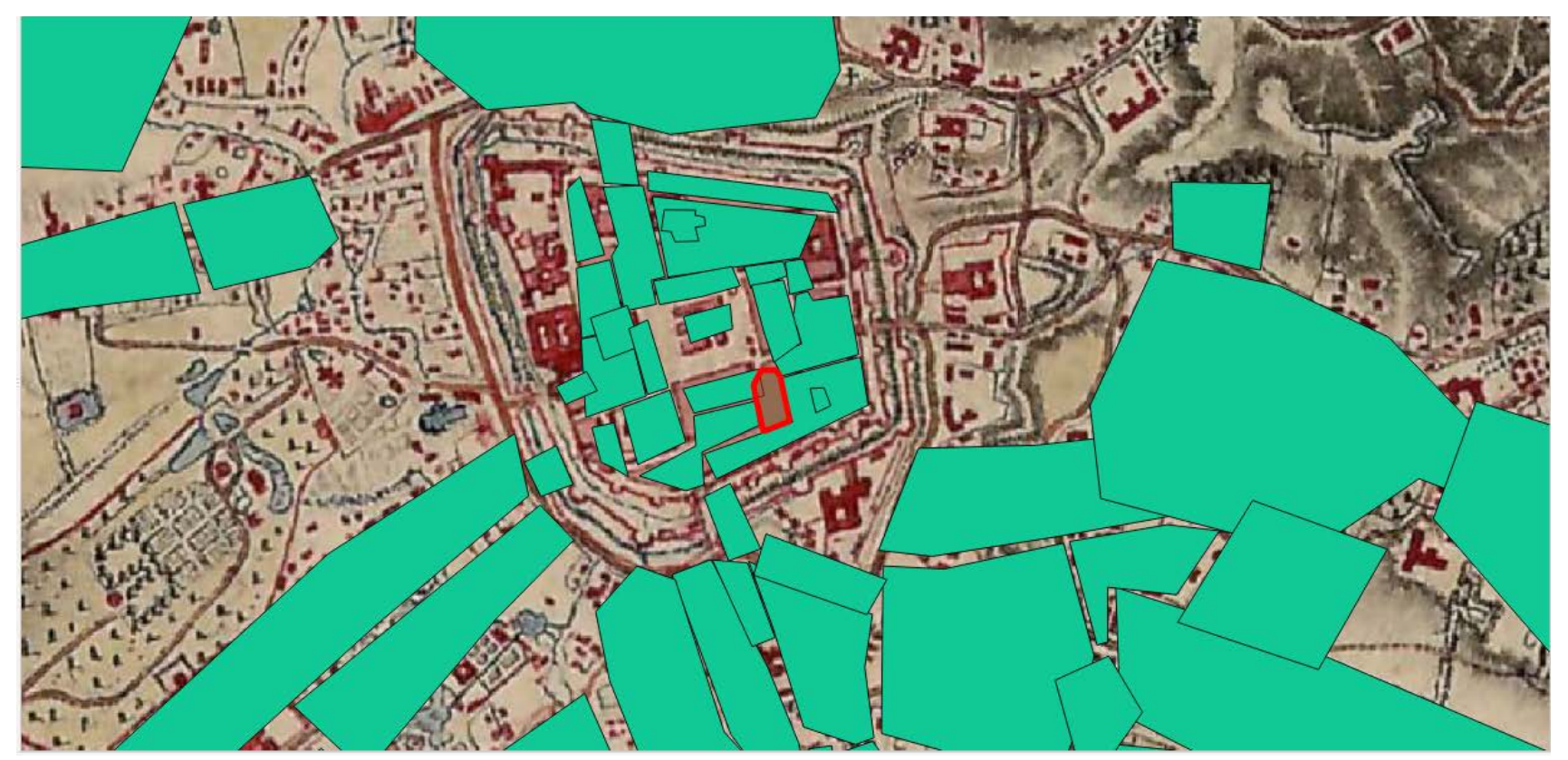

Потрібно звернути увагу на те, що локалізація вулиць на карті - умовна, адже назви вулиць належать до понять, які не мають чітких меж. Хоча локалізації пробігання вулиць у середмісті неабияк сприяла правильна і незмінна паралельно-перехресна планувальна структура. На передмістях ретроспективну локалізацію вулиць здійснила М. Долинська ${ }^{27}$, зокрема на основі «Інвентаря ста ланів», тож об'єкти, відображені на карті (вулиці XVII-XVIII ст.), умовно ретроспективно локалізовані за ії працями. Також потрібно врахувати, що за основу взято карту XVIII ст., яка не відображала реалії пізньосередньовічного і раньомодерного часу. Могло змінюватися все, зокрема русла потоків і річок унаслідок викопування ставів, і навіть горби зникали за умови, що з них видобували каміння 
${ }^{28}$ Капраль, М. (Ред.) (2014). Атлас українських історичних міст (Т. 1: Львів). Київ: Картографія, $28,37-40$.

Рис. 2. Вигляд структури бази даних 3 прикладом зміни назви «Зарванська»

${ }^{29}$ Перші писемні згадки подано за міською книгою 1382-1389 рр., що є найстарішою збереженою книгою, оскільки, як пише Б. Зиморович, 1381 року дерев’яний Львів згорів і «втратили архів міста 3 державними документами». Та все ж, варто пам'ятати, що багато середміських вулиць отримали свої назви ще задовго до цієї дати. або пісок для будівельних потреб. Такі зміни спричиняли зміни мережі шляхів і доріг, виникали нові осади на передмістях, з XVII ст. бурхливо й потужно розбудовувалася система передміських укріплених монастирів ${ }^{28}$, а також фільварків. Тож на одній карті важко відобразити зміни, які відбулися з територією за майже чотири століття, але зіставлення назв однієї території за певний час дає відповіді на деякі запитання. Розглянемо нижче найцікавіші, які вдалося з’ясувати.

За натискання на об'єкт-вулицю, на екрані з'являється вікно з інформацією з бази даних (рис. 2) у хронологічному порядку. У такий спосіб можна простежити першу згадку про вулицю та зміни в назві упродовж майже 400 років. Дані можна відфільтрувати за роками, мовою оригіналу (скажімо, відобразити лише назви німецькою мовою), архівною справою та іншими категоріями.

\begin{tabular}{|c|c|c|c|c|c|c|c|c|c|c|c|c|c|}
\hline \\
\hline \multicolumn{2}{|c|}{$\begin{array}{l}\text { id } 40 \\
\text { - Ralation1 }\end{array}$} & & & & & & & & & & & & \\
\hline \multicolumn{13}{|c|}{ 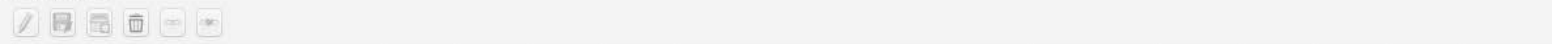 } & \multirow{2}{*}{ 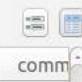 } \\
\hline & str_name & str_id & day & month $y$ & year - & str_translate & str_sourse & urse_pa! & fond & opys & 5 sprava & str_lang & \\
\hline 64 & Zerwanska vlica & 40 & 20 & 5 & 1618 & Зарванська вулиця & ЦДІАЛ & 686 & 52 & & 2773 & pol & \\
\hline 65 & Zerwanszka Vlicza & 40 & NULL & NULL & 1620 & Зарванська вулиця & ЦДААЛ & 12 & 52 & & 2775 & pol & \\
\hline 66 & Zarwanska vlica i Skoczki Targ & 40 & NULL & NULL & 1621 & Зарванська вулиця і Скотський рин... & . ЦДААЛ & 60 & 52 & & 2775 & pol & \\
\hline 67 & Zarwanska ulica i Skocki targ & 40 & 20 & 5 & 1622 & Зарванська вулиця і Скотський рин... & . ЦДІАЛ & 204 зв. & 52 & & 2775 & pol & \\
\hline 68 & Zerwanska ulica & 40 & NULL & NULL & 1623 & Зарванська вулиця & ЦДІАЛ & 26638. & 52 & & 2775 & pol & \\
\hline 69 & Zerwanska ulica & 40 & NULL & NULL & 1624 & - Зарванська вулиця & ЦДІАЛ & 32738. & 52 & & 2775 & pol & \\
\hline 70 & Zerwanska Vlica & 40 & 10 & 12 & 1630 & Зарванська вулиця & ЦЦДІАЛ & 41 & 52 & & 2777 & pol & \\
\hline 71 & Serbansska Vlica & 40 & 23 & 4 & 1631 & Сербанська вулиця & ЦДААЛ & 135 & 52 & & 2777 & pol & \\
\hline 72 & Zerwanszka ulica & 40 & 13 & 9 & 1632 & Зарванська вулиця & ЦДІАЛ & 253 & 52 & & 2778 & pol & \\
\hline 73 & Zerwanska Vlica & 40 & 10 & 11 & 1634 & Зарванська вулиця & ЦДІАЛ & 337 & 52 & & 2777 & pol & \\
\hline 74 & Serbanska alias Zerwanska nazwana & 40 & 14 & 4 & 1636 & Сербанська або зерванська названа & ЦДІІАЛ & 546 & 52 & & 2777 & pol & \\
\hline 75 & Serbanska ałs Zerwanska Vlica & 40 & 15 & 3 & 1637 & Сербанська або зерванська вулиця & ЦДААЛ & 557 & 52 & & 2780 & pol & \\
\hline 76 & Vlica Zerwanszka & 40 & 22 & 4 & 1637 & Зарванська вулиця & ЦДІАЛ & 770 & 52 & & 2777 & pol & \\
\hline 77 & Vlica Zerwanszka & 40 & 15 & 3 & 1638 & Вулиця Зарванська & ЦДІАЛ & 912 & 52 & & 2777 & pol & \\
\hline 78 & Vlica Zerwanszka & 40 & 12 & 7 & 1640 & Вулиця Зарванська & ЦДААЛ & 70 зв. & 52 & & 2779 & pol & \\
\hline 79 & Serbanska als Zerwanska Vlica & 40 & 30 & 5 & 1642 & Сербанська або зерванська вулиця & ЦДААЛ & 18238. & 52 & & 2779 & pol & \\
\hline 80 & Serbanska als Zerwanska Vlica & 40 & 6 & 11 & 1643 & Сербанська або зерванська вулиця & ЦДІАЛ & 224 зв. & 52 & & 2779 & pol & \\
\hline
\end{tabular}

Від міських брам простягались дві однойменні з брамами вулиці - Краківська і Галицька. Назва вулиці Галицької вперше згадується 1384 р. ${ }^{29}$ та незмінно існує до наших днів, тобто це найстаріша назва вулиці, що жодного разу не зазнала перейменувань. До таких, що не зазнали змін, також можна було б віднести назву вулиці Краківської, але з 1382 до 1417 р. у джерелах трапляється інша назва цієї вулиці - Татарська. Прикро, що за 1417-1441 pр. немає збережених документів, за якими 
30 Зубрицький, Д. (2006). Хроніка міста Львова (перекл. $з$ польськ. І. Сварника; комент.

М. Капраля; ред. О. Шишка, Ю. Бірюльов). Видання друге, виправлене і доповнене. Львів: Центр Свропи, 60.

31 Зашкільняк, Л., \& Крикун, М. (2002). Історія Польщзі: Від найдавніших часів до наших днів. Львів: Львівський національний університет ім. I. Франка, 40.

${ }^{32}$ Schugasse / platea Sutorum / vlicza Sewcza.

${ }^{33}$ Пол. Vlicza ku fortcze.

${ }^{34}$ Пол. Vlicza Sewcza ku fortcze.

35 Зубрицький, Д. Хроніка міста Львова, 212, 218.

${ }^{36}$ Пол. Iezuiczka vlicza.

${ }^{37}$ Пол. Iezuiczka albo sewska ulica.

${ }^{38}$ Пол. vlica Szewska ku Iezuitom.

\footnotetext{
${ }^{39}$ Лam. platea Zarwanska.
}

можна було б дослідити, як змінювалась назва з Татарської на Краківську. Бартоломей Зиморович під 1403 р. у своїй відомій хроніці пише, що «Татари, руськими князями міським правом обдаровані, ...але, багато [раз] були визнані винними у викраденні шляхетних хлопчиків і дівчаток, усім стадом за мури міста виселені». Та цю тезу, ще свого часу, в середині XIX ст., розвінчав історик Денис Зубрицький. Він пише, що Зиморович жив у той час, коли у викраденні християнських дітей звинувачували євреїв, тож бурмістр, заодно, засуджує і татар. Також Зубрицький вказує на те, що татари жили і сплачували податки в місті нарівні з іншими, це були спокійні ремісники і торгівці, тож «для чого їм були ці викрадення? Приховати дітей серед себе вони не могли. Передати кочівним татарам теж. Зрештою дітей і не брали в ясир, забирали лише сильних та рослих, щоб використати їх для роботи або продати» ${ }^{30}$. Тому, на його думку, татарські мешканці час від часу приймали християнську віру й асимілювалися серед польського, руського чи вірменського населення. Можна додати, що 3 XV ст. підвищується статус Кракова як «історичної столиці» ${ }^{31}$, дорога до якої зі Львова й починалася 3 названої вулиці. Тож назву «Краківська» щодо брами і вулиці починають вживати все частіше Отже, назва вулиці Краківської побутує з 1441 р. і до сьогодні.

Назва вулиці «Шевська» протягом 150 років (1444-1594 рр.) зафіксована в єдиному варіанті ${ }^{32}$ Потім дуже короткий час (1597-1602 рр.) вживали «вулиця до фіртки» ${ }^{33}$ або «вулиця Шевська до фіртки» ${ }^{34}$. За прізвищами платників податків, це та сама Шевська. 31603 по 1618 рр. трапляється уставлена назва: vlicza Sewcza. У 1610 р. було закладено наріжний камінь єзуїтського костелу, а саме місце під забудову було віддано єзуїтам ще у 1603 p. ${ }^{35}$

У 1622 р. вперше згадано Єзуїтську вулицю ${ }^{36}$, яка вже у 1623 р. стає Єзуїтською або Шевською ${ }^{37}$. Помітно, що упродовж майже двадцяти років сприйняття простору навколо будівництва храму в міщан змінювалось. Об'єкт (костел єзуїтів), який з'являвся на тлі міста, слугував найкращим орієнтаційним пунктом для міщан і гостей міста. Тож не дивно, що назва у 1636 р. трохи змінюється на «вулиця Шевська до Єзуїтів» ${ }^{38}$. У такому напрямковому варіанті вживають до 1674 р., після чого знову повертається назва «вулиця Шевська», яку застосовують до 1767 р. Тобто з 1622 р. і до кінця XVIII ст. міщани знали і користувались двома назвами. Можна припустити, що в уяві міщан дуальність назви не дезорієнтовувала і не викликала відчуття нефункціональності. Спосіб називництва вулиць, як бачимо, був досить гнучким і розвивався пліч-о-пліч зі змінами на тлі міста і запитами суспільства.

Податкові реєстри переписували з року в рік протягом XVI-XVIII ст. Часто писарі брали за взірець реєстри попередніх років і лише позначали ту чи ту суму сплачених коштів. Завдяки такому переписуванню до нас дійшла сучасна назва вулиці Сербської. Хоча з 1483 р. у джерелах вона згадується під назвою вулиця Зарванська ${ }^{39}$. 
40 Зіморович, Б. (2002). Потрійний Львів: Leороlis Triplex. Львів: Центр Свропи, 57.

${ }^{41}$ Там само, 200

42 Зубрицький, Д. Хроніка міста Львова, 13.

43 Там само.

44 Там само.

${ }^{45}$ Janeczek, A. (1999). Ulice etniczne w miastach Rusi Czerwonej w XIV-XVI wieku. Kwartalnik Historii Kultury Materialnej, 47 (1-2), 142.

${ }^{46}$ Пол. Vlicza Skocza ÿ Zerwanica.

${ }^{47}$ Пол. Skoczka Vlica ku Zerwaniczy idac.

48 Подвійний варіант «Сербанська або Зерванська вулиця» вживали упродовж 45 років. Самі писарі не були впевнені, яка назва була оригінальною, тож писали дві.
Першим до появи різнотлумачень цієї назви спричинився Б. Зиморович, написавши: «Сарацени, відомі 3 невіри у Христа та викрадення християнських хлопчиків, були вигнані з цілої Русі. Проте вулиця, на якій вони колись мешкали, хоча й залишена ними, спочатку називалася Сараценською, пізніше, від викрадення названа Зарванською і донині носить ганебне ім'я» ${ }^{40}$. Б. Зиморович, мабуть, сам себе заплутав, адже схожий пасаж є і про вулицю Татарську. Міська легенда про викрадення християнських дітей представниками інших національностей перейшла 3 однієї вулиці на іншу і міцно вкорінилась у свідомості людей (згодом у цьому звинувачуватимуть і євреїв). У часи Б. Зиморовича (XVII ст.) назву вживали у варіанті «Zerwanska vlica». У примітках до перекладу твору Б. Зиморовича Наталія Царьова звертає увагу, що «Зиморович пояснює походження назви в дусі народної етимології: “зарванська” від польського слова “zerwać” (викрадати)»"1, тобто на цій вулиці жили сарацини та викрадали дітей.

Головним міфотворцем щодо походження цієї назви все ж є Д. Зубрицький. Він не погоджується зі словами Зиморовича, що «Зарванська вулиця отримала свою назву від сарацинів» ${ }^{42}$, і натомість висуває власну помилкову гіпотезу, яка, незважаючи на неточність, все ж дуже вкорінилася. Потрібно зазначити, що в час, коли жив Зубрицький (перша половина XIX ст.), цю назву вже вживали у варіанті «Vlica Serbanska», тож він цілком для себе логічно пов’язує ііі з сербами, «бо на ній вони [серби], прибуваючи з товарами до Львова, жили разом із греками» ${ }^{43}$. Та все ж він звертає увагу, що назва була дуже мінливою: «Сербанська, Серванська, Зарванська, Зарваниця» ${ }^{44}$.

Польський історик Анджей Янечек спростовує віднесення цієї назви до етнічних (тобто сараценів або сербів). Він пише: «Відповідно до словникових значень, “zarwanica” означає місце, повне галасу, шуму i, особливо, коли його вживали щодо міського простору - галасливий (людний) вуличний ринок» ${ }^{45}$. Тут варто звернути увагу, що вулиця Зарванська у Львові була дотичною 3 вулицею чи то ринком Скотським. Цю тезу підтверджують назви 3 джерел: «вулиця Скотська і зарваниця» ${ }^{46}$ (1616 р.), «Скотська вулиця, йдучи до Зарваниці» ${ }^{47}$ (1634 р.) тощо.

Звідки взялась Сербська? Щоб це зрозуміти, потрібно створити ланцюжок оригінальних варіантів написання цієї вулиці: platea Zarwanska $\rightarrow$ platea Zeruanska $\rightarrow$ Zeruaniensis platea $\rightarrow$ Vlica Zarwanska $\rightarrow$ Vlica Serbanska $\rightarrow$ Serbanska albo Zerwanska vlica $\rightarrow$ Vlica Serbanska.

У досліджуваних шосових реєстрах звук [3] часто передавався на письмі літерою «s»: Sigmunt/ Zigmunt, Lazarowicz/Lasarowicz, Zeidikowicz/Seidikowicz, zdomu/sdomu та ін. До цих прикладів також належить Zeruanska/Serbanska, де початкові великі літери «Z» і «s» були досить схожими в написанні. Назву «Сербанська» вперше зафіксовано в 1631 р. В наступному 1632 р. знову запис «Зерванська». Вище зазначена в ланцюжку «Сербанська або Зерванська» з’явилась 1636 р., і в такому дуальному варіанті іï записували до 1672 р. щорічно ${ }^{48}$ (рис. 2). 3 цього ж року і надалі записували лише вулицю «Сербанську». Неточність у записі 1631 р. і послідовне вживання подвійної 
${ }^{49}$ Лam. platea et foro peccorum.

${ }^{50}$ Лam. platea fori pecorum.

${ }^{51}$ Пол. Vlicza Skoczka.

${ }^{52}$ Пол. Vlica Skockiego targu.

53 Зубрицький, Д. Хроніка міста Львова, 13.

${ }^{54}$ Janeczek, A. Ulice etniczne, 142. назви в подальшому призвело до пошуків етимології назви «Сербанська». Тож Д. Зубрицький свого часу помилково припустив походження «Сербанської» від сербів. Таким способом Сербанська стає Сербською, яку знаємо і дотепер.

Неподалік вулиці Зарванської, як уже з'ясувалось, була вулиця Скотська. 31484 р. до 1529 р. вживають лише денотат «вулиця», у 1533 р. трапляється у варіанті «вулиця і ринок Скотський»49. Згодом словосполучення «Скотський ринок» стає власною назвою: вулиця Скотський ринок ${ }^{50}$. Певний час вживали назву «вулиця Скотська» ${ }^{51}$ (1598-1640рр.). Остаточним і найуживанішим варіантом залишилась «вулиця Скотського ринку»" (1641-1767рр.). Про цю вулицю Д. Зубрицький писав таке: «На ній торгували шотландські купці, хоча й не мали своїх будинків, тож вулиця звалася Шотландським торгом і Шотландською вулицею» ${ }^{53}$. «Хоча шотландці і справді мігрували до польських земель, - коментує Зубрицького А. Янечек, - щоправда з другої половини XVI ст., і відомо, що вони займалися справою купецькою, проте не варто втрапляти у пастки польської мови. Це не вулиця Szkocka, але Skocka, від слова skot, “худоба"»" ${ }^{54}$ Всі сумніви розвінчуються, якщо звернутись до латинського оригіналу: Forum Pecorum - Ринок Худоби.

Звичайно, джерел, у яких можна натрапити на назви вулиць, є дуже багато. Це можуть бути і судові справи, і тестаменти, і метричні книги, і міські постанови та багато інших. Але з зафіксованих назв уже можна зробити певні висновки, а відображення назв на карті та їх систематизація по роках сприятиме глибшому розумінню утворення та зміни назв. Також, завдяки такій геоінформаційній системі, можна здійснювати пошук у базі даних за кількома критеріями, фільтрувати результати за роками, мовами чи архівними справами. На відміну від будь-якого графічного редактора, який може лише зобразити об'єкти як малюнок або карту, ГІС має просторову прив'язку та необмежені можливості щодо інформації, яка може бути прикріплена до об'єкта. Завдяки сучасним технологіям, особливо геоінформаційним, на історичних мапах можна відобразити не лише вулиці, а й інші топографічні об'єкти та урбаноніми, а також аналізувати ці дані.

На основі геоінформаційної системи з вулицями Львова і, зокрема, створення бази варіантності назв упродовж майже чотирьох століть вдалось з'ясувати генезу назв вулиці Зарванської, яка трансформувалась у сучасну назву вулиці Сербської. А також вказати оригінальне походження назви вулиці Скотської та спростувати певні історіографічні тези. Окрім того, в результаті відстеження змін назви вулиці Шевської, доведено, що уявлення простору міщанами впливало на називництво в місті.

\section{References}

Czaja, R., \& Noga, Z. (2015). "Heterogeniczność przestrzeni miejskiej w Królestwie Polskim i Rzeczypospolitej Obojga Narodów w epoce przedprzemysłowej”. Kwartalnik Historii Kultury Materialnej, 63 (2), 183. 
Czołowski, A. (Wyd.). (1892). Pomniki dziejowe Lwowa z archiwum miasta (Tom I. Najstaesza księga miejska 1382-1389). Lwow.

Czołowski, A. (Wyd.). (1896). Pomniki dziejowe Lwowa z archiwum miasta (Tom II. Księga przychodow i rozchodów miasta 1404-1414). Lwow.

Czołowski, A. (Wyd.). (1905). Pomniki dziejowe Lwowa z archiwum miasta (Tom III. Księga przychodow i rozchodów miasta 1414-1426). Lwow.

Czołowski, A., \& Jaworski, F. (Wyd.). (1921). Pomniki dziejowe Lwowa z archiwum miasta (Tom IV. Księga ławnicza miejska 1441-1448). Lwow.

Dolynska, M. (1996). Retrospektyvna metoda doslidzhennia zabudovy seredmistia Lvova. Urbanistychno-arkhitekturni problemy mist Halychyny. Lviv, 56-62.

Dolynska, M. (1999). Ukrainski kvartaly v chasi avstriiskoho periodu Lvova. Knyha mist Halychyny. Mizhdystsyplinarni doslidzhennia u mistoznavstvi. Visnyk Derzhavnoho universytetu "Lvivska politekhnika”, 379, $199-204$.

Dolynska, M. (2001). "Vstup do sotsiotopohrafiii", yak uzahalnenyi metod istoryko-arkhivnykh poperednikh doslidzhen v restavratsii arkhitekturnykh obiektiv. Visnyk Natsionalnoho universytetu "Lvivska politekhnika". Arkhitektura, 429, 166-173.

Dolynska, M. (2006). Istorychna topohrafiia Lvova XIV-XIX st. Lviv: Vydavnytstvo Natsionalnoho universytetu "Lvivska politekhnika".

Gregory, I. N. A Place in History: A Guide to Using GIS in Historical Research. Retrieved from http://hds.essex. ac.uk/g2gp/gis/index.asp.

Janeczek, A. (1999). Ulice etniczne w miastach Rusi Czerwonej w XIV-XVI wieku. Kwartalnik Historii Kultury Materialnej, 47 (1-2), 142.

Kapral, M. (1997). Vlasnyky nerukhomosty seredmistia Lvova 30-40-kh rokiv XVI stolittia u svitli shosovykh reiestriv (sotsiotopohrafichnyi aspekt). Zapysky Naukovoho tovarystva imeni Shevchenka, 233: Pratsi Istorychno-filosofskoi sektsii, 148 .

Kapral, M. (Ed.) (2014). Atlas ukrainskykh istorychnykh mist (T. 1: Lviv). Kyiv: Katohrafiia.

Krypiakevych, I. (1965). Toponimika staroho Lvova. Naukovo-informatsiinyi biuleten arkhivnoho upravlinnia URSR, 5 (67), 85-87.

Krypiakevych, I. (1991). Istorychni prokhody po Lvovi. Lviv: Kameniar.

Melnyk, B. (2001). Dovidnyk pereimenuvan vulyts i ploshch Lvova. XIII-XX stolittia. Lviv: Svit.

Petryshyn, H. (2006). "Karta F. Fon Miga” (1779-1782 rr.) yak dzherelo do mistoznavstva Halychyny. Lviv: Vydavnytstvo Natsionalnoho universytetu "Lvivska politekhnika".

Tsentralnyi derzhavnyi istorychnyi arkhiv Ukrainy, m. Lviv (mahistrat m. Lvova). F. 52, op. 2, spr. 8, 9, 10, 769-813.

Zashkilniak, L., \& Krykun, M. (2002). Istoriia Polshchi: Vid naidavnishykh chasiv do nashykh dniv. Lviv: Lvivskyi natsionalnyi universytet im. I. Franka.

Zimorovych, B. (2002). Potriinyi Lviv: Leopolis Triplex. Lviv: Tsentr Yevropy.

Zubrytskyi, D. (2006). Khronika mista Lvova. Lviv: Tsentr Yevropy. 


\section{Vira Orysia}

\section{THE GENESIS AND FUNCTIONING}

\section{OF STREET NAMES IN MEDIEVAL LVIV}

According to the "spatial turn," space in cities are considered not only in the context of social processes but also as a product of human activity and imagination. Street naming is an integral part of the human vision of space in cities. In the medieval and early modern times, the names were inextricably linked to the objects, artisans, or communities residing in the territory. Due to this, I can classify street names and trace their origins.

Often, the street naming is mentioned in the renaming directories and studied, mainly, at the local lore level, especially in Lviv. It means that street names in Lviv sometimes became the subject of speculation and have overgrown with centuries-old myths. My research aims to clarify the renaming processes, study the genesis of such names, and display them on a map using a geo-information system. That will explain and makes us better understand their formation. So, I present an advanced methodology of researching street names in Lviv.

As the first step in this research, I created a database of the street names in Lviv in 1382-1768 years. The tax records were the primary source, and the city council books were the auxiliary source. In this database, every street name has a unique ID. Then, I created the Geo-informational system [application QGIS 2.18]. It has three layers, where: layer one contains the Friedrich von Mieg's map of Lviv (XVIII century), layer two has a modern map, and layer three contains the objects (streets), to which names from the database are merged. Because of the ID, the application extracts only the desired street name and chronologically displays its development. It allows us to analyze the changes in street names, their approximate location, and understand the origins of some myths in Lviv's street naming.

For example, analyzing the development of street name "Sutorum/Szewska" (Cobbler street) I have proved that the building and appearance of the Jesuit church have affected to the perception of the adjacent space, so the street name became dual: "Jesuit or Szewska street". The second example shows that street name "Zarwanska/Serbanska" comes from the old-polish word, which means "loud market”, but not from the Serbians that came to Lviv much later, than street name appeared.

Keywords: Lviv, street names, geoinformation technologies, Zarvanska street, Cobbler street. 